\title{
Graptolite biostratigraphy of the Shihtien Formation (Darriwilian) in West Yunnan, China
}

\author{
ZHANG YUANDONG, FAN JUNXUAN \& LIU XIAO
}

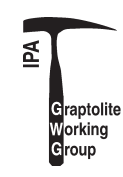

\begin{abstract}
A rich mid-Ordovician graptolite fauna is reported from the Shihtien Formation at Baoshan and Shidian in West Yunnan Province, SW China. The fauna comprises Didymograptus artus, D. murchisoni, D. spinulosus, Pterograptus sp., Hustedograptus vikarbyensis, H. teretiusculus, Archiclimacograptus angulatus, A. riddellensis, Haddingograptus oliveri, Proclimacograptus angustatus, and dendroids such as Dictyonema, Ptilograptus, Dendrograptus, Callograptus, indicating an age of mid- to late Darriwilian. Based on the fauna, two graptolite assemblages are recognized, in ascending order, the Didymograptus artus and Didymograptus murchisoni biozones. The graptolite fauna shows a considerable similarity to those contemporary in Baltica and the Yangtze Region of South China. - Key words: graptolites, biostratigraphy, Darriwilian, Ordovician, West Yunnan, China.
\end{abstract}

ZHANG, Y.D., FAN, J.X. \& LIU, X. 2009. Graptolite biostratigraphy of the Shihtien Formation (Darriwilian) in West Yunnan, China. Bulletin of Geosciences 84(1), 35-40 (3 figures). Czech Geological Survey, Prague. ISSN 1214-1119. Manuscript received July 20, 2008; accepted in revised form October 16, 2008, 2009; published online November 14, 2008; issued March 31, 2009.

Zhang Yuandong (correspoding author), Fan Junxuan \& Liu Xiao, State Key Laboratory of Palaeobiology and Stratigraphy, Nanjing Institute of Geology and Palaeontology, China; ydzhang@nigpas.ac.cn (corresponding e-mail),fanjunxuan@yahoo.com

West Yunnan has been widely regarded as a constituent of the Sibumasu Terrane (sometimes called the Shan-Thai Terrane or Paleoplate) during the Ordovician (Chen \& Rong 1992; Fortey \& Cocks 1998, 2003; Metcalfe 1998). The terrane embraces West Yunnan, East Burma, most of the Malay Peninsula and Sumatra, and is bounded to the east in Yunnan by the Changning-Menglian Suture (Fang et al. 1992, Liu et al. 1993, Metcalfe 1998). The affinity of the Sibumasu Terrane with other blocks or continents, such as South China, North China, and Gondwana, remains uncertain, partly because of poor fossil discoveries in Sibumasu (see Zhou \& Zhen 2008). Fortey \& Cocks (1998, 2003) concluded that the carbonate succession of the Cambrian-Ordovician transition interval in the terrane displays strong similarity to that in North China and central Australia, whereas those trilobite faunas of the later Ordovician are nearly identical with those of South China, despite the fact that Caradoc brachiopods from Burma show a modest level of endemism (Cocks \& Zhan 1998).

The Ordovician rocks of West Yunnan have been poorly known until now. Though reported present in many localities, the Ordovician rocks were strongly affected by tectonic activities of many phases, especially the recent Himalayan that commenced in the Palaeogene. The earliest geological work in the region were carried out by L.V.
Loczy in 1880, and J.C. Brown in 1908-1910. Loczy (1893) reported the first discoveries of Ordovician trilobites from the region, and Brown $(1913,1916)$ published a primary introduction to the Ordovician and Silurian rocks. Abundant fossils collected during Brown's investigation, including cystoids, crinoids, brachiopods, gastropods, cephalopods, trilobites and graptolites, were subsequently published by Reed (1917); the graptolites, mostly from Silurian rocks, were identified by Gertrude Elles (in Reed 1917) as of Llandovery age. Yin \& Lu (1937) collected and described the Jenhochiao section (now called Banpo) in Shihtien (modern pinyin transliteration, Shidian). They reported the discovery of Ordovician brachiopods, trilobites, cephalopods and graptolites including Didymograptus nanus, Didymograptus sp. indet., Dictyonema sp., and Desmograptus? sp., which were described briefly and illustrated by Yin (1937). A subsequent investigation of the Baoshan region in West Yunnan by Sun in 1938 resulted in a tripartite subdivision of the Ordovician rocks (Sun 1945): the Shihtien Formation (Arenigian and Llanvirnian, in which Didymograptus nanus and Didymograptus murchisoni were reported); the Lower Hungshuitang Formation (Llandeilian); and the Upper Hungshuitang Formation (Caradocian). Yu (1962) described some additional graptolite species that he assigned to Ptilograptus and a new genus Zigzagigraptus. 


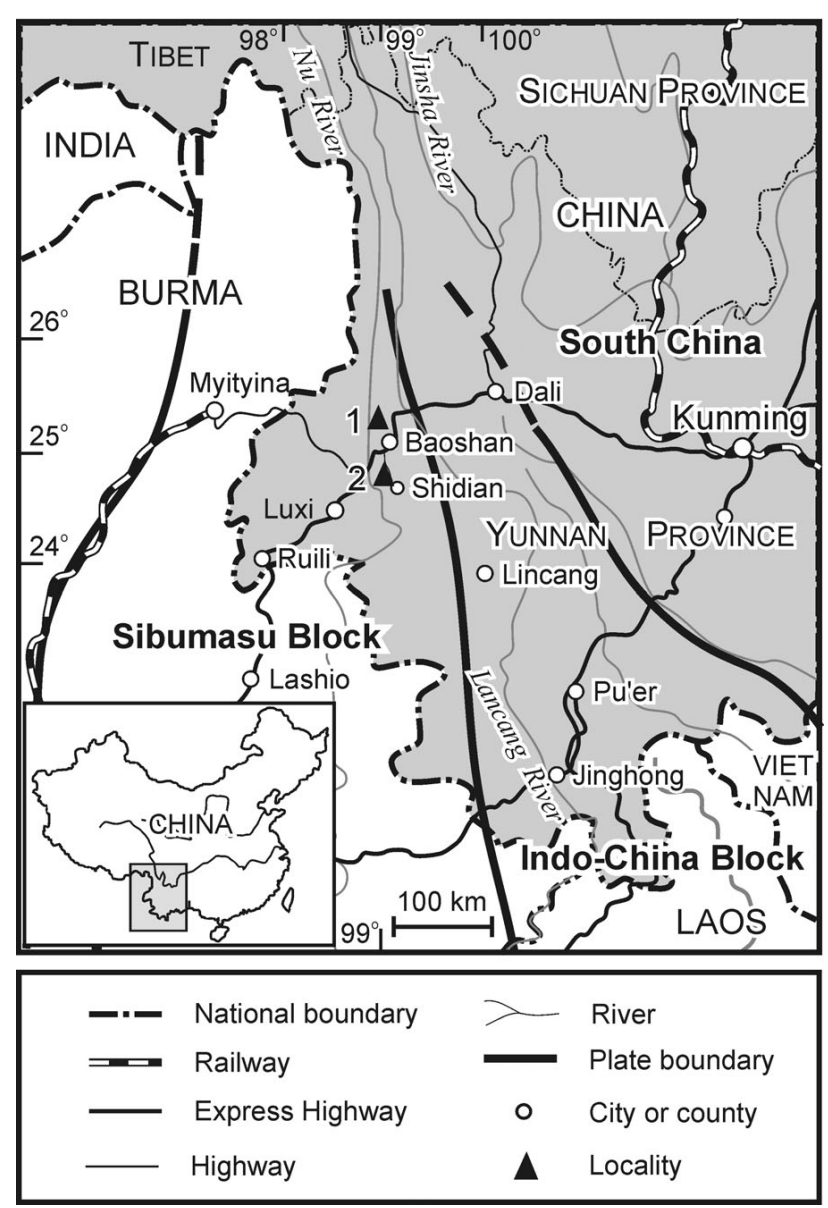

Figure 1. Location of the Laojianshan section in Baoshan, and the Banpo section in Shidian, West Yunnan, China.

\section{Lithological sequence of the Ordovician strata}

We have recovered a more diverse Ordovician graptolite fauna from both the Banpo section in Shidian and the Laojianshan section in Baoshan than has previously been reported from the region (Fig. 1). The Laojianshan section

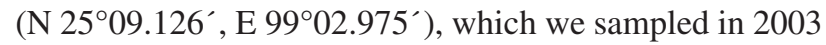
and 2007, is located at Laojianshan Mountain near Upper Yanqing village, $\mathrm{ca} 17 \mathrm{~km}$ to the northwest of downtown
Baoshan City. The section, exposed along the country road from Zhugeyin Town to Yangliu Town, includes a complete sequence of Ordovician strata that, in ascending order, comprise the Yanqing, Mantang, Laojianshan, Shihtien, and Pupiao formations (see Yunnan Geological Survey 1980).

The Yanqing Formation is composed of sandstone with a few layers of laminated limestone and siltstone, and contains trilobites, cystoids and conodonts, indicating an early Tremadocian age. The Mantang Formation consists of sandstone and siltstone, and is regarded as late Tremadocian in age, based on a few brachiopods and graptolites of Rhabdinopora flabelliformis, which have been reported from other nearby sections (Yunnan Geological Survey 1980). The Laojianshan Formation is $743 \mathrm{~m}$ thick, and typified by purple-red and greenish-grey sandstone, siltstone and shale, with developed fine lamination, cross-bedded and graded sequences. The interbedded greenish-grey shale contains a few trilobites and graptolites (Callograptus and Didymograptus). More graptolites were found in other sections nearby, and based on these, three graptolite biozones have been recognized, in ascending order Acanthograptus, Didymograptus protobifidus, and Undulograptus austrodentatus biozones (Yunnan Geological Survey 1980), suggesting an age spanning Floian to earliest Darriwilian for the formation. However, the graptolites are not yet described.

The Shihtien Formation overlies conformably the Laojianshan Formation and underlies conformably the Pupiao Formation. It is typified by greenish-grey and green-yellow siltstone and shale, with a few layers of thin-bedded micrites, containing fairly abundant graptolites, trilobites and brachiopods of Darriwilian age. The formation was derived from the original 'Shihtien Beds' of Brown (1916), which was later split by Yin \& Lu (1937) into a 'Shihtien bed' (lower) and a 'Hengshuitang Limestone' (upper). The 'Shihtien bed' was further redefined as the 'Shihtien Formation', which refers to the lithology and interval as we use them here, whereas the 'Hengshuitang Limestone' was renamed as the Pupiao Formation (Yunnan Geological Survey 1980). The Pupiao Formation is typified by purple-red and greenish-grey siltstone, shale and micrite, with

Figure 2. Illustration of the Darriwilian graptolites from the Shihtien Formation, mid-Ordovician, West Yunnan. • A, B - Archiclimacograptus riddellensis (Harris, 1924); A - NIGP149274 (BSSD-4-8), B - NIGP 149275 (BSSD-4-24). C , D - Archiclimacograptus angulatus (Bulman, 1953); C - NIGP 149279 (BSSD-4-21a), D - NIGP 149277 (BSSD-4-21b). • E, F, L - Hustedograptus vikarbyensis (Jaanusson, 1960); E - NIGP 149261 (BPSD-1-19), F - NIGP 149259 (BSSD-4-38), L - NIGP149260 (BSSD-4-58). • G, H, M - Hustedograptus teretiusculus (Hisinger, 1840); G - NIGP149272 (BPSD-1-46), H - NIGP149270 (BPSD-1-55), M - NIGP149273 (BSSD-4-37). • I, K, N, Q - Didymograptus murchisoni (Beck, 1839); I - proximal part of mature specimen, NIGP149281 (BPSD-1-32); K - proximal part of mature specimen with developed membrane, NIGP149282 (BPSD-1-15); N - proximal part of mature specimen with typical pakrianus-like membrane, NIGP149256 (BPSD-1-18); Q - NIGP149255 (BSSD-4-40). • J - Pterograptus sp.; NIGP149239 (BPSD-1-25). O, R-T - Didymograptus artus Elles \& Wood, 1901; O - proximal part showing the origination of th $2^{1}$ from th $1^{1}$, NIGP149283 (BSSD-3-24); R - NIGP149246 (BSSD-4-8), S - NIGP149284 (BSSD-4-1); T - juvenile specimen showing slender proximal part, NIGP149240 (BPSD-1-3). P - Eoglyptograptus dentatus (Brongniart) sensu Bulman, 1963, NIGP149264 (BSSD-4-21). All the scale bars are $1 \mathrm{~mm}$ in length. BSSD-samples at the Laojianshan section, BPSD-samples at the Banpo section. 
Zhang Yuandong et al. - Graptolite biostratigraphy of the Shihtien Formation, Darriwilian, China

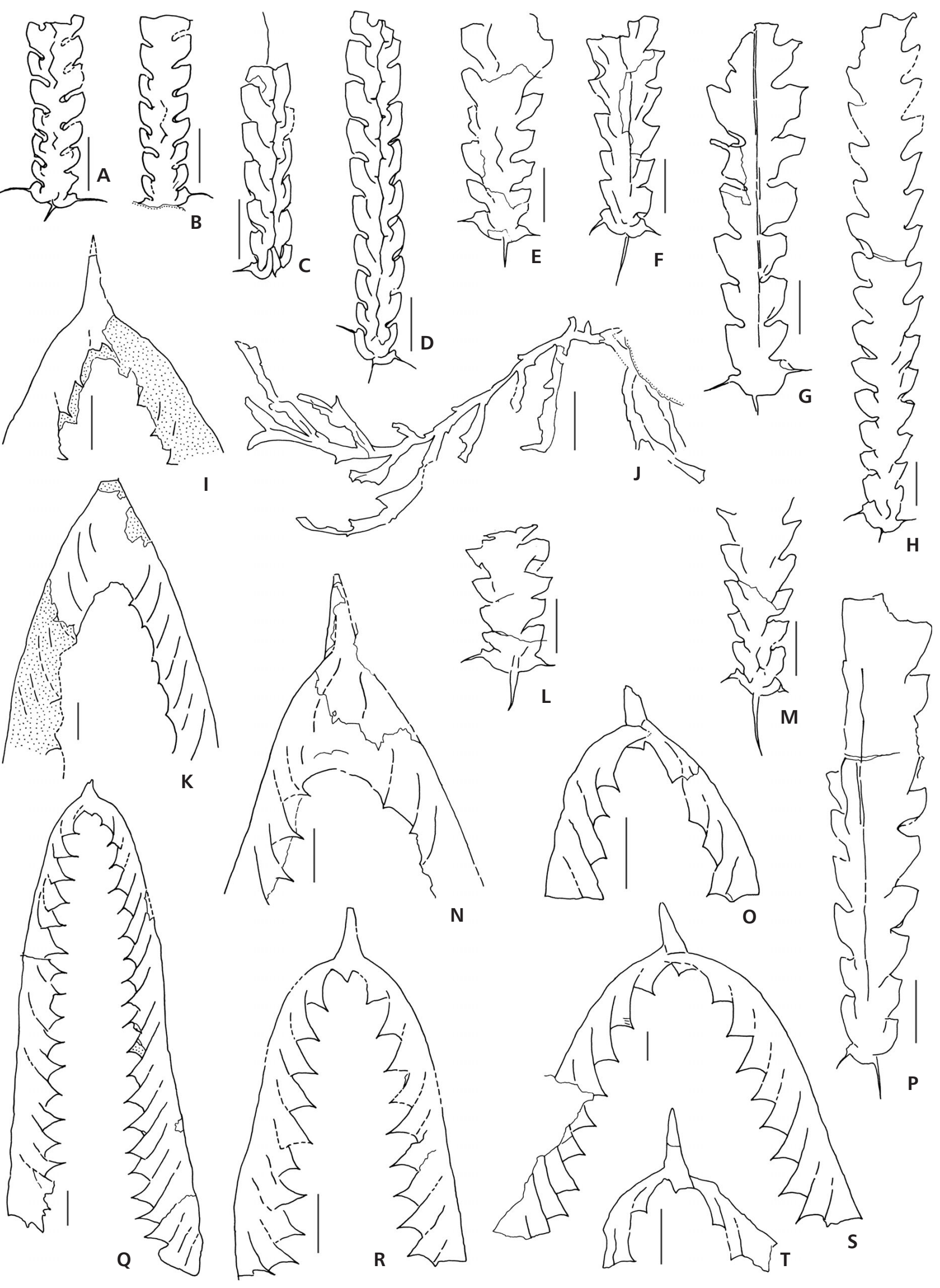




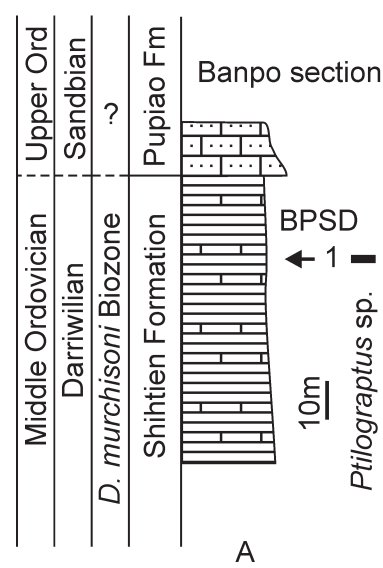

A
BPSD

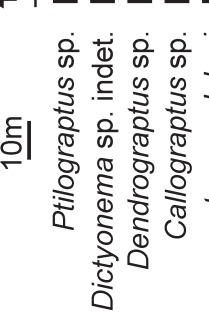

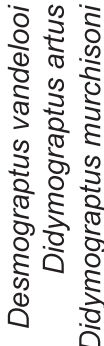

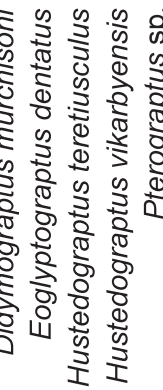

Legends

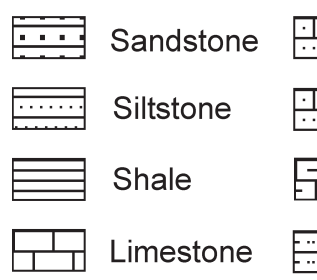

Siltstone with calcareous siltstone

Calcareous siltstone

Argillaceous limestone

Muddy siltstone
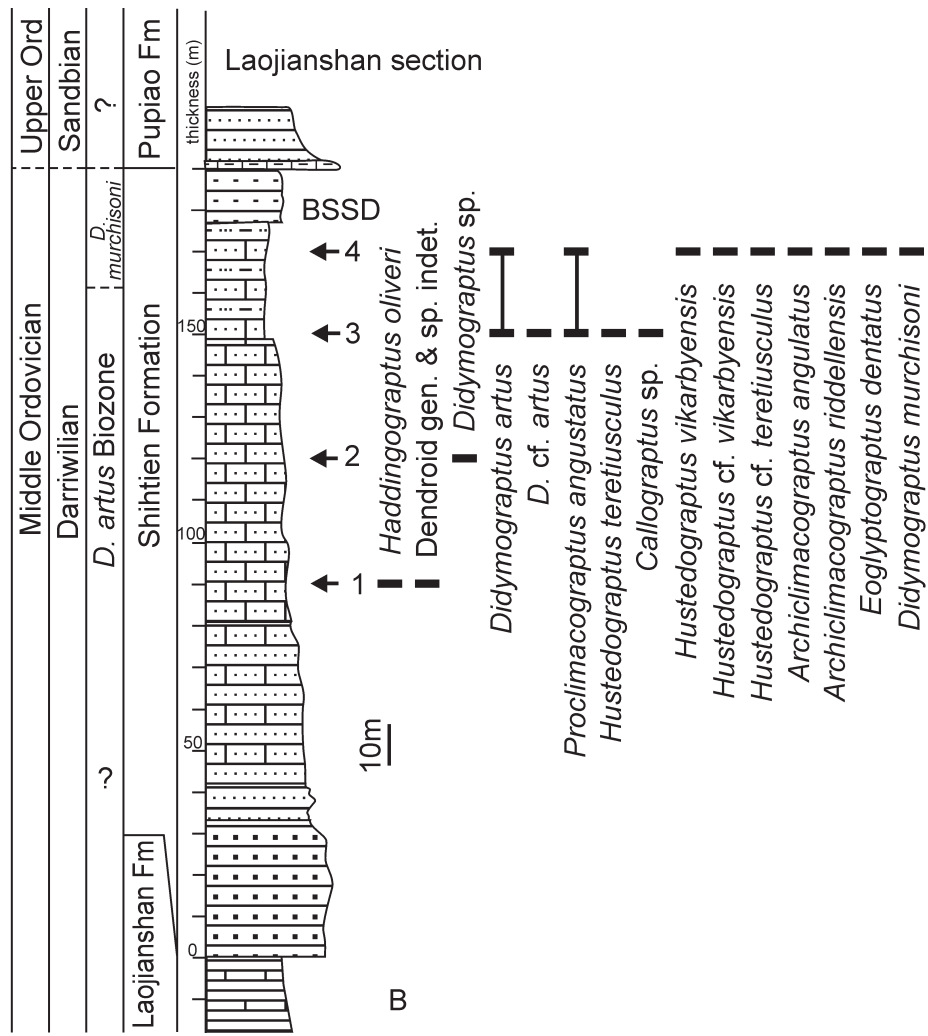

Figure 3. Range chart of the Darriwilian graptolites in the Laojianshan and Banpo sections, West Yunnan.

its base defined at the first appearance of purple-red layers, and its top at the appearance of black shale and chert (Jenhochiao Formation, Llandovery).

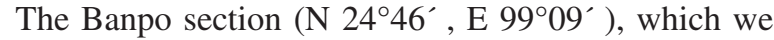
sampled in 2007, is located at Banpo village of Renheqiao (formerly spelt as Jenhochiao) Town, $c a 6 \mathrm{~km}$ to the north of Shidian County town (and ca $60 \mathrm{~km}$ from Baoshan). The section includes the Shihtien, Pupiao and Jenhochiao formations, and is moderately affected by tectonics. In the upper part of the Shihtien Formation, we discovered the rich Darriwilian graptolite fauna illustrated here (Fig. 3).

\section{Graptolite biostratigraphy and correlations}

Elles identified the graptolites collected by Brown in his pioneer expedition as including Didymograptus murchisoni, D. murchisoni geminus, D. indentus and Climacograptus cf. scharenbergi, which suggested an age of the Didymograptus murchisoni Biozone (Brown 1916, Reed 1917). The rocks bearing these graptolites were assigned by Brown into the basal part of the 'Pupiao Beds', but later included into the upper part of the redefined 'Shihtien Formation' by Yin \& Lu (1937). The latter found additional Didymograptus nanus and some dendroids from the rocks, which indicated an earliest Llanvirn age of the 'Didymograptus bifidus' Biozone (= D. artus Biozone).
Our collection includes a more diverse fauna of graptolites (Figs 2, 3), including Didymograptus artus, D. murchisoni, D. spinulosus, Pterograptus sp., Hustedograptus vikarbyensis, $H$. teretiusculus, Archiclimacograptus angulatus, A. riddellensis, Haddingograptus oliveri, Proclimacograptus angustatus, and dendroids such as Dictyonema, Ptilograptus, Dendrograptus, Callograptus. The fauna is fairly similar to those found in Norway (Berry 1964, Maletz 1997) and the Yangtze Region of South China (Zhang et al. 2007). Based on the occurrences of the fauna, two graptolite biozones, in ascending order the Didymograptus artus Biozone and the Didymograptus murchisoni Biozone, are recognized herein (Fig. 3).

\section{Didymograptus artus Biozone}

The abundance biozone is recognized by the predominant occurrences of the eponymous species, together with Haddingograptus oliveri, Proclimacograptus angustatus, Hustedograptus teretiusculus, uncertain species of Didymograptus, and some dendroids (Fig. 2). These graptolites occur mainly in the upper part of the Shihtien Formation. Sample BSSD-3 yielded abundant D. artus and associated graptolites, as well as rich trilobites (e.g., Birmanites yunnanensis and Illaenus sp.). Samples BSSD-1 and BSSD-2 
contained relatively fewer specimens of graptolites and trilobites, of which a few specimens are identified as Didymograptus sp. but no unequivocal $D$. artus can be confirmed. Therefore, the base of the D. artus Biozone is uncertain. The lower part of the Shihtien Formation, composed of sandstone and calcareous sandstone, contains no graptolites. However, Undulograptus austrodentatus was found from the top part of the underlying Laojiangshan Formation in some other sections near Shidian (Yunnan Geological Survey 1980, p. 33), and hence the lower part of the Shihtien Formation probably corresponds to the transition interval between the $U$. austrodentatus and $D$. artus biozones, equivalent to the Undulograptus intersitus Biozone of the Yangtze Region (South China, Zhang \& Chen 2003, Zhang et al. 2007) and Australasia (VandenBerg \& Cooper 1992), and the Undulograptus dentatus Biozone of North America (Maletz 2005). The D. artus Biozone in west Yunnan is comparable with that recognized in Changning, Sichuan, South China (Zhang et al. 2007), and in Britain (Fortey et al. 1995, 2000). It may also correspond to the Nicholsonograptus fasciculatus Biozone and the lower part of Pterograptus elegans Biozone in the Jiangnan region of South China (Zhang et al. 2007) and in Baltica (Maletz 1997).

\section{Didymograptus murchisoni Biozone}

This abundance biozone is characterized by a proliferation of the eponymous species, together with common biserials, including Hustedograptus teretiusculus, H. vikarbyensis, Archiclimacograptus riddellensis, Archicl. angulatus, Eoglyptograptus dentatus, rare Pterograptus sp. and some dendroids. Didymograptus artus and Proclimacograptus angustatus, which first appear in the underlying $D$. artus Biozone, also extend into this biozone. Hustedograptus teretiusculus is fairly common in this biozone, but the species has been proved as long-ranging in both Baltica and South China, and thence is biostratigraphically less significant. The species Hustedograptus vikarbyensis, Archiclimacograptus riddellensis and A. angulatus, as well as Eoglyptograptus dentatus (sensu Bulman), all first appear in the upper Pterograptus elegans Biozone of Norway (Maletz 1997), indicating a correlation of the D. murchisoni Biozone in West Yunnan to the upper P. elegans Biozone in Baltica. The occurrence of Pterograptus sp., although with only one specimen in BPSD-1, further supports this correlation. The D. murchisoni Biozone is also well correlated with the same biozone in Britain (Fortey et al. 1995, 2000), the Yangtze region of South China (Zhang et al. 2007), the lower part of the Archiclimacograptus riddellensis Biozone in Australia (VandenBerg \& Cooper 1992), and the Pterograptus elegans Biozone in Argentina (Brussa et al. 2003a, b).
No graptolites have been found from the top part of the Shihtien Formation and the entire Pupiao Formation in the region, and thus no graptolite zones younger than the Didymograptus murchisoni Biozone can be identified.

\section{Acknowledgments}

We are indebted to Luo Huilin of Kunming Institue of Geology and Mineral Resources, Xiao Yinwen of the Yunnan Geological Survey, and our colleague Wang Yi for providing information and assistance in the field. We thank Zhou Zhiyi (NIGPAS) for identifying the trilobites, and Chuck Mitchell and Petr Kraft for helpful reviews that improved the manuscript. Financial support from the Chinese Academy of Sciences (KZCX2-YW-122), the Ministry of Science and Technology (2006CB806402, 2006FY120300-4), and the Natural Science Foundation of China (40532009) is acknowledged. This is a contribution to UNESCO-IUGS IGCP 503 project "Ordovician and Silurian Palaeogeography and Palaeoclimatology" and the "Geobiodiversity Database" project (www.geobiodiversity.com).

\section{References}

BECK, D. in MURCHISON, R.I. 1839. The Silurian System. 786 pp. John Murray, London.

BERRY, W.B.N. 1964. The Middle Ordovician of the Oslo Region, Norway. Norsk Geologisk Tidsskrift 44(1), 61-170.

BRown, J.C. 1913. Contributions to the geology of the Province of Yunnan in western China. (3). Notes on the stratigraphy of the Ordovician and Silurian beds of western Yunnan. Records of the Geological Survey of India 1913 (Part 3), 327-334.

BROWN, J.C. 1916. Contributions to the geology of the Province of Yunnan in western China. (5). Geology of parts of the Salween and Mekong valleys. Records of the Geological Survey of India 47(4), 205-266.

Brussa, E.D., Mitchell, C.E., ORTega, G., Maletz, J. \& AstinI, R.A. 2003a. Middle Ordovician graptolite biostratigraphy from the Los Azules Formation at Los Gatos Creek, Central Precordillera, Argentina, 21-25. In ORTEGA, G. \& ACEnOlaZA, G.F. (eds) Proceedings of the $7^{\text {th }}$ International Graptolite Conference \& Field Meeting of the International Subcommission on Silurian Stratigraphy. Instituto Superior de Correlacion Geologica (INSUGEO), Tucumán.

Brussa, E.D., Toro, B.A. \& BenedetTO, J.L. 2003b. Biostratigraphy, 75-90. In BENEDETTO, J.L. (ed.) Ordovician Fossils of Argentina. Universidad Nacional de Cordoba, Cordoba.

BULMAN, O.M.B. 1953. Some Graptolites from the Ogygiocaris Series (4aa) of the Oslo district. Arkiv för Zoologi 1(17), 509-517.

BULMAN, O.M.B. 1963. On Glyptograptus dentatus (Brongniart) and some allied species. Palaeontology 6(4), 665-689.

CHEN, X. \& RONG, J.Y. 1992. Ordovician plate tectonics of China and its neighbouring regions, 277-291. In WEBBY, B.D. \& LAURIE, J.R. (eds) Global Perspectives on Ordovician Geology. A.A. Balkema, Rotterdam. 
COCKS, L.R.M. \& ZHAN, R.B. 1998. Caradoc brachiopods from the Shan States, Burma (Myanmar). Bulletin of the Natural History Museum London (Geology) 54(2), 109-130.

ElLES, G.L. \& WoOD, E.M.R. 1901. A monograph of British graptolites, Part 1 - Dichograptidae. 54 pp. Palaeontographical Society, London.

FANG, Z.J., ZHOU, Z.C. \& LIN, M.J. 1992. A discussion about the problems concerning the Changning-Menglian suture zone from the stratigraphical point of view. Journal of Stratigraphy 16(4), 292-303.

FORTEY, R.A. \& COCKS, L.R.M. 1998. Biogeography and palaeogeography of the Sibumasu terrane in the Ordovician: a review, 43-56. In HALL, R. \& HollowAY, J.D. (eds) Biogeography and Geological Evolution of SE Asia. Backhuys Publishers, Leiden.

FORTEY, R.A. \& COCKS, L.R.M. 2003. Palaeontological evidence bearing on global Ordovician-Silurian continental reconstructions. Earth-Science Reviews 61(2003), 245-307. DOI $10.1016 / \mathrm{S} 0012-8252(02) 00115-0$

Fortey, R.A., HARPER, A.T., INGHAM, J.K., OWEN, A.W. \& RUSHTON, A.W.A. 1995. A revision of Ordovician series and stages from the historical type area. Geological Magazine 132(1), 15-30.

Fortey, R.A., HARPer, A.T., Ingham, J.K., OWEN, A.W., PARKes, M.A., Rushton, A.W.A. \& WoOdCOCK, N.H. 2000. A revised correlation of Ordovician Rocks in the British Isles. Geological Society, London Special Report 24, 1-83.

HARRIS, W.J. 1924. Victorian graptolites (new series), Part I. Proceedings of the Royal Society of Victoria 36(2), 92-106.

Hisinger, W. 1840. Lethaea Suecica seu Petrificata Suecica, supplementum $2.11 \mathrm{pp}$. Holmiae, Stockholm.

JAANUSSON, V. 1960. Graptoloids from the Ontikan and Viruan (Ordov.) limestones of Estonia and Sweden. Bulletin of the Geological Institutions of the University of Uppsala 38(4), 289-365.

LIU, B.P., FENG, Q.L. \& FANG, N.Q. 1993. Tectonic evolution of Palaeo-Tethys Poly-Island-Ocean in Changning-Menglian and Lancanjiang belts, southwestern Yunnan, China. Earth Science - Journal of China University of Geosciences 18(5), 529-539.

LOCZY, L.V. 1893. Die Wissenschaftlichen Ergebnisse der Reise des Grafen Béla Széchenyi in Ost-Asien. Volume 1. 767 pp. Hölzel, Wien.

MALETZ, J. 1997. Graptolites from the Nicholsonograptus fasciculatus and Pterograptus elegans zones (Abereiddian, Ordo- vician) of the Oslo region, Norway. Greifswalder Geowissenschaftliche Beiträge 4, 5-98.

MALETZ, J. 2005. Early Middle Ordovician graptolite biostratigraphy of the Lovisefred and Albjära drill cores (Scania, southern Sweden). Palaeontology 48, 763-780.

\section{DOI $10.1111 / \mathrm{j} .1475-4983.2005 .00482 . x$}

METCALFE, I. 1998. Palaeozoic and Mesozoic geological evolution of the SE Asian region: multidisciplinary constraints and implications for biogeography, 25-41. In HALL, R. \& HOLLOWAY, J.D. (eds) Biogeography and Geological Evolution of SE Asia. Backhuys Publishers, Leiden.

REED, F.R.C. 1917. Ordovician and Silurian Fossils from Yun-nan. Memoirs of the Geological Survey of India, Palaeontologica Indica (New Series) 6(3), 1-69.

SuN, Y.C. 1945. The Sino-Burmese Geosyncline of Early Palaeozoic Time with Special Reference to its Extent and Character. Bulletin of the Geological Society of China 25, 1-7.

VANDENBERG, A.H.M. \& COOPER, R.A. 1992. The Ordovician graptolite sequence of Australasia. Alcheringa 16, 33-85. DOI $10.1080 / 03115519208619032$

YIN, T.H. 1937. Brief Description of the Ordovician and Silurian Fossils from Shihtien. Bulletin of the Geological Society of China 16 (special volume in honour of Ding Wenjiang), 281-298.

YIN, T.H. \& LU, C.H. 1937. On the Ordovician and Silurian Beds of Shihtien, Western Yunnan. Bulletin of the Geological Society of China 16 (special volume in honour of Ding Wenjiang), 41-56.

YU, J.H. 1962. Graptolites (Ptilograptidae) from West Yunnan. Bulletin of Nanjing University (Geology) 2, 47-54.

YUNNAN GEOLOGICAL SURVEY 1980. Regional Geological Report (Baoshan, with 1/200,000 Geological Map) - Ordovician System, 26-42. Yunnan Geological Survey, Baoshan.

ZHANG, Y.D. \& CHEN, X. 2003. The Early-Middle Ordovician graptolite sequence of the Upper Yangtze region, South China, 173-180. In AlBANESI, G.L., BERESI, M.S. \& PERALTA, S.H. (eds) Ordovician from the Andes. Universidad Nacional de Tucuman, Tucuman 17.

ZHANG, Y.D., CHEN, X. \& GOLDMAN, D. 2007. Diversification patterns of Early and Mid Ordovician graptolites in South China. Geological Journal 42(3-4), 315-337.

ZHOU, Z.Y. \& ZHEN, Y.Y. 2008. Trilobite-constrained Ordovician biogeography of China with reference to faunal connections with Australia. Proceedings of the Linnaean Society of New South Wales 129, 183-195. 